177 KNUT OVE ELIASSEN

Professor, allmenn litteraturvitenskap

Norges teknisk-naturvitenskapelige universitet - Trondheim

\title{
STRANDENS TOPOLOGIER
}

"Welcome to the world of Plastic Beach, some kind of nature", sang i 2010 Damon Albarn på Gorillaz' album Plastic Beach, og han fortsatte, "It's a Casio on a plastic beach, it's a Styrofoam deep sea landfill", før sangen ebbet ut i codaen, "Plastico, plastico, plastico where the green, green grows". Knapt ti år senere, på Venezia-biennalen i 2019, avslutter Lina Lapelytè, Vaiva Grainytè og Rugilè Barzdžiukaitès vinnerverket, strandoperaen (!) Sun and Sea (Marina) med "feriegjestenes kor":

This year the sea is as green as a forest: Eutrophication! // Botanical gardens are flourishing in the sea - The water blooms. // Our bodies are covered with a slippery green fleece, our swimsuits are filling up with algae, empty snail homes, swollen seaweed, fish remains, and all kinds of shells...

At stranden lenge har vært et fokuspunkt i det internasjonale økologiske ordskiftet, henger sammen med at plastforsøplingen av verdens kyster er et åpenlyst, lett kommuniserbart og ikke minst mobiliserende uttrykk for klodens på mange måter begredelige tilstand. Forsøplede strender står i grell kontrast til det badelivets estetikk som i reisebyråenes reklamer lover en forsmak på paradis, eller rett og slett Sea, Sun \& Sex. Masseturismens 
178 KULTUR \& KLASSE *130*2020 STRANDEN

strand signaliserer fritid og forlystelser, den er både et objekt for nytelse og et symbol på livsbejaende utfoldelser. Utenfor bylivets tid og rom er strender frisoner underlagt andre sosiale koder enn byrommets; de står for natur, frihet og ørkesløshet. Det er nok mye av grunnen til at den sjøvannsblekede plastposen som formløst dupper i vannkanten, er et så godt eksempel på den estetiske forurensningen Mary Douglas kalte matter out of place (Douglas). Plastposens symbolske pollusjon - i brenningen truer den skillet mellom natur og kultur, organisk og syntetisk - gir den en affektiv kraft som overstiger den enkelte posens reelle skadevirkninger på strandsonens økologiske systemer.

"Mens Jacob lar tankene flyte melankolsk av sted, dukker kadaveret til en fryser opp i synsfeltet hans, båret frem av lagunens tunge bølger. Det er ikke alene, det ledsages av noen computerskjermer samt skjelettet til en heller livløs fargeprinter" (Poix 22). ${ }^{1}$ I Guillaume Poix' prisbelønte roman fra 2017, Les fils conducteurs ('Ledetrådene') tjener den unge ghaneseren Jacob og hans venner til livets opphold ved av å samle kobberledninger fra søppel som driver i land - elektriske forbrukervarer fra verden over. Deres hverdag er en påminnelse om at stranden, lenge før den ble den frie tidens arena, var et sted for arbeid og utkomme. Jacob kunne kalles for en postmoderne beachcomber. Ordet betegnet opprinnelig bølger store nok til å overskylle stranden, men det ble fra 1800-tallet av brukt som navn på akterutseilte sjømenn som tjente til livets opphold ved å samle drivgods i randsonene av havneområder utenfor Europa. Dette er imidlertid langt fra en aktivitet som kun hører den industrielle kapitalismen til. I Danmark-Norge ble bruken av kysten utførlig regulert ved Christian Vs lov, skjønt den lovmessige reguleringen av strandsonen går enda lenger tilbake. Bølger har alltid ført gjenstander av mulig verdi til stranden, om det nå dreide seg om forliste skip, drivgods, en døende hval, tang eller brensel, og eierskapet til disse ressursene har alltid vært omstridt. Slik er denne arkaiske formen for økonomisk virke fortsatt utbredt også i det 21. århundre, i Afrika - hos Poix' Jacob i Accra - eller i Asia, hvor søppelsanking på stranden er ett av

1 Oversettelsen er min, som for øvrig de andre oversettelsene i teksten hvor ikke annet er markert. 


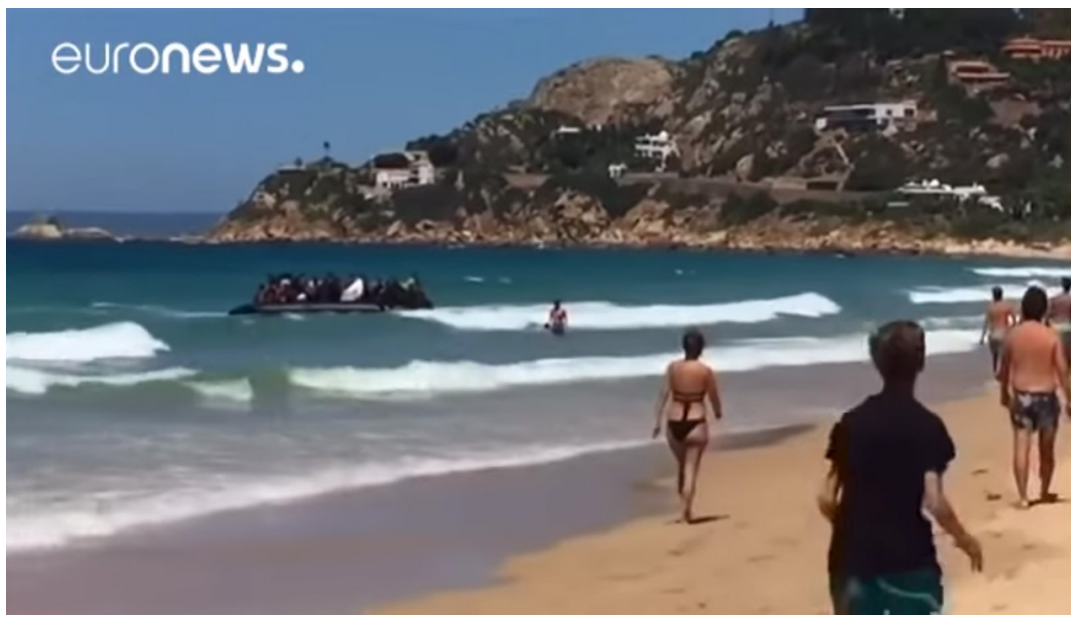

Fig. 1. Playa de los alemanes, $B B C$ 10 aug. 2017

globaliseringens mest slående uttrykk og et instruktivt bilde på hvordan moderniseringsprosessens mange ulike tempi flettes sammen.

Badestranden er en annen type strand enn Jacobs, den er underlagt fritidens regime, og det bølgene måtte bringe inn, oppfattes som forurensning, fremmedlegemer, matter out of place. Et slående eksempel er TV-bildene fra 2017 av afrikanske migranter som lander en gummibåt på Playa de los alemanes og desperat stormer i land mellom strandkledde turister travelt opptatt med ferielivets formålsløse lediggang. Bildene av løpende afrikanere på Solkysten vekker komplekse assosiasjoner; i et kommentarfelt på YouTube kan man lese "More like an invasion" ("A Boat Full"). Henvisningen er åpenbart til filmklisjeen "amfibisk invasjon" kjent fra storbudsjetts amerikanske krigsfilmer fra Allan Dwans The Sands of Iwo Jima (1949) til Steven Spielbergs Saving Private Ryan (1998). Men strandens plass i migrasjonens historie, både den frivillige og den tvungne, er langt eldre og mer kompleks. En utvidet kontekstualisering vil i TV-bildene åpenbare en annen og eldre historie, treskipenes og slaveriets historie. Da vil man i emigrantene kunne gjenkjenne havarister eller til og med flyktende slaver som redder seg $\mathrm{i}$ land.

Landskap er ikke gitt fra naturens side, de blir til og finner sin vei inn i litteratur og kunst som emne og ressurs. Den litterære topologien 
leverer redskap til å analysere kulturgeografiens skiftende realiteter. De innledende eksemplene foreslår at det er kulturanalytisk produktivt å studere stranden $i$ lys av litterær topologi. Siden den litterære tradisjonen har opparbeidet "stranden" til å bli et allmennsted, et locus communis (Curtius Europäische Literatur), er den blitt et magasin for kulturell erindring. Men om stranden ofte anvendes som verdiladet setting, vekker den estetiske bruken av den - gitt modernismens utpregede selvrefleksivitet - lett en annenordensestetikk. Saving Private Ryan kan ikke unngå å sitere forløperen The Sands of Iwo Jima. Gjenkjennelighet såvel som allusjon inngår i toposets måte å fungere på. Dermed kan også topoi fungere ironisk som når "amfibisk invasjon" blir fortolkningsskjema for filmsnutten med de ulovlige immigrantene. Effekten er en semantisk og affektiv inversjon. Heller enn ett etablert skjema gir kulturelt pregede landskap som strender rom til knipper av topoi hvis betydningsspill betinges av familielikheter, kontekstualiseringer, allusjoner og sitater.

En lang og kompleks historie har utstyrt strandtopoiene med en semantisk polyvalens. Det er forutsetningen for at de så smidig lar seg reartikulere i andre sammenhenger. Stranden er slik ikke kun scene for invasjon eller heroisme, masseturisme eller forurensningsdystopier, men også for traumer og overgrep. Britiske film- og videokunstnere med immigrantbakgrunn som Isaac Julien og John Akomfrah har i videoarbeider som The Leopard (Western Union Small Boats) fra 2007 og Vertigo Sea fra 2017 utforsket stranden som et topos i menneskerovets historie. Begge fremhever sjøens komplekse rolle i den afro-europeiske historien samtidig som de går i dialog med litterære universer. Når Julien legger The Leopard til Lampedusa, er det ikke kun fordi øya er et kjent ankomstpunkt for afrikanske immigranter, han lar også Giuseppe Tomasi di Lampedusas roman Il gattopardo (1958) og Carlo Viscontis film med samme navn (1963) komme til syne. Akomfrah går derimot i dialog med en karibisk tradisjon representert ved Derek Walcotts metalitterære diktepos Omeros (1990) og plasserer samtidig sitt eget verk i så vel den episke tradisjonen etter Homer som innenfor en lang historie om imperialisme. ${ }^{2}$

2 Jeg er Frederik Tygstrup takk skyldig for å ha gjort meg oppmerksom på Akomfrahs og Juliens to videoarbeider. 
Didaktikken i Akomfrahs og Juliens arbeider tydeliggjør hvordan "strandens" historiske realitet alltid allerede er under forhandling. John R. Gillis' uttrykk, The Human Shore, betegner resultatet av et arbeid som materielt har sedimentert seg i spor etter fysisk slit, konflikter og vold. Men også idealstranden som feriebransjens og underholdningsindustriens massive påtrykk har lyktes med å installere subretinalt i store lag av verdens reiseglade mellomlag, er et eminent uttrykk for det den britisk-karibiske sosiologen Stuart Hall kaller the work of culture (Hall, Evans \& Nixon).

\section{TOPOLOGISK MELLOMSPILL}

E. R. Curtius fremhever i sin historiske topikk frekvens og konstans som viktige aspekter ved toposet. Et topos er et autopoetisk "skjema", en litterær konstellasjon som har utfelt seg gjennom alminnelig bruk, usus ("Historisk topik"13). Valget av ordet "skjema" peker på både toposets mønsterkarakter, at det setter ulike elementer sammen, og at det kan anvendes på forskjellige typer materialer. Topoi er ikke bare fortolkningsfigurer, de er også litterært produktive; de inngår i den verktøykisten av dikteriske ressurser tradisjonen stiller til rådighet for dikterne.

Det er her trolig på sin plass å fremheve et prinsipielt skille mellom topoi og metaforer og arbeidet de utfører. Mens den siste er en forkortet simile som iverksetter en transposisjon av en semantisk verdi fra ett betydningsregister til et annet, har den første i tillegg til den semantiske implikasjonen også karakter av argument. Som scene for et resonnement er toposet også et rom for mulige handlingssekvenser; "gitt a så b", er et minimalt forløp. Hva utsagnskraft angår, er topoi betinget av et meningsfellesskap mellom dikter og publikum. Deres overførbarhet krever nødvendigvis at de inngår i en delt tradisjon, doxa, noe som tas for gitt. Som scene, mulig plot og implisitt resonnement, er toposet spatio-temporalt og organiserer tid og rom på et vis som er gjenkjennlig for lesere eller tilskuere.

Curtius' Europäische Literatur und lateinisches Mittelalter får sin argumentasjonskraft fra kvantiteten av eksempler, eller i klassiske retoriske termer, copia. Et stort antall forekomster av intuitivt sammenlignbare litterære passasjer, formler eller figurer, gjøres til rekker eller serier og 
182 KULTUR \& KLASSE *130*2020 STRANDEN

leverer belegg for et gitt topos' realitet; eksempler kunne være verdensboken, statsskipet og, ikke minst, "der Lustort", det behagelige stedet, locus amoenus (Europäische 202). Toposets formelkarakter har to umiddelbare implikasjoner, det kan gjentas og det er velkjent. Dets litterære effektivitet ligger i at det repeterer noe publikum allerede vet. I kraft av at det uttrykker det tradisjonen har tatt vare på - gesunkenes Kulturgut - er det implisitt av normativ karakter. Ethvert forsøk på å bestemme det må nødvendigvis være tilbakeskuende og dermed reviderende. Toposet samler i seg historiske serier av det som ligner, men som ikke er identisk. På grunn av variasjonene vil serien alltid tendere mot å underminere toposets karakter av positivt bestemt generalfigur. For til syvende og sist er det usus, de til enhver tid dominerende bruksmåtene som leverer nøklene til å dechiffrere serien. Dette utstyrer toposet med et metalitterært aspekt, alt står i relasjon til eldre gestaltninger. Av den grunn kan man i prinsippet alltid kunne tenke seg andre serier, både som supplerer, men også som omformer, travesterer eller oppløser etablerte topoi. Verdensboken, statsskipet og der Lustort kan bli til hhv. verdensveven, romskipet Jorden eller Plastic beach. Topoi som i en gitt sammenheng presser seg på som aktuelle, blir i kraft av sin relevans også fortolkningsnøkler til det magasin av topoi som til enhver tid er levende.

I forlengelsen av nyere aktualiseringer av Curtius' toposlære (Dahl et al.) er ambisjonen med artikkelen å identifisere noen av den europeiske litteratur- og kulturhistoriens viktigste estetiske og litterære topoi slik de mobiliseres i samtidens økologiske, politiske og økonomiske interesse for stranden. Formålet er å identifisere estetiske og litterære formler fra dagens usus og drøfte dem som bærere av mer eller mindre deklarerte verdisynspunkt, ideologi, som via bruk utsettes for betydningsglidninger som røper aktuelle forhandlinger. Disse strandtopoi vil stå mest sentralt: Stranden som en randsone underlagt egne lover og regler; stranden som den frie tidens sted og arena for sanselig utfoldelse; stranden som arbeidssted; stranden som katastrofenes sted; stranden som et skjønnhetens sted og endelig stranden som antropogen og politisk realitet.

Når stranden har blitt et så kraftfullt topos for krisebevissthet, kan det neppe kun forstås i lys av det tyvende århundrets masseturisme, men 
skyldes at en økende del av klodens befolkning bor ved havet (Gillis 187). Rekkefølgen topoiene behandles i, uttrykker et forsøk på å gripe noen regulariteter i de økonomier som preger den aktuelle bekymringen for stranden, og noen av de forskjellige måtene den fremstår på, med en term fra Bruno Latour, som a matter of concern. Analysens utgangspunkt følger usus, seriens logikk, og lar badestranden levere figurene som utgjør analysens utgangpunkt, da den som en aktuelt dominerende utmynting av strandtoposet retroaktivt refunksjonaliserer eldre strandtopoi. Eminent historiske kulturlandskap er strender også uttrykk for en overhistorisk eller dyp tid, hvilket innledningsvis krever noen ord om deres egenart som fysisk randsone og det prehistoriske substratum i deres materielle realitet.

\section{DE MANGE STRENDER}

Om beach betegner en gruskvalitet, et steinslag som forekommer hyppig på britiske strender, og shore betegner strandkanten, grensen mellom vann og land (etymologisk i slekt med både "skjær" og "å skjære"), så betegner substantivet strand en lokalitet, historisk er ordet forbundet med "rand", altså semantisk til "marg" og "grense". The seaside er derimot et landskap ved havet. Mens cliffs gjerne inngår i the seaside, er de ikke en del av the beach, mens man derimot i Norge har strandtypen svaberg, som er populært som utgangspunkt for badeliv.

Om stranden er en grense og en randsone, the marginal world, med Rachel Carsons formulering (The Edge of the Sea 1), er det kontekst- og situasjonsbestemt hvorvidt den er havets grense mot tørt land eller det tørre landets grense mot det våte element. Reversibiliteten gir en semantisk labilitet som er avgjørende for at stranden kan fylle så mange forskjellige og komplekse funksjoner. Disse kan tentativt oppsummeres i fire bestemmelser: I egenskap av å være naturgitte barrierer for menneskelig aktivitet er strender grenser som skiller. De er ankomstpunkter og dermed også scener for begynnelser og avslutninger. De er rom i egen rett. Endelig gjør deres umiddelbare nærhet til havet dem utsatte, de er konkrete symboler for kontingens idet de kan bli borte som en følge av erosjon, stormfloder, flodbølger, klimaendringer eller menneskelig manipulasjon. 
184 KULTUR \& KLASSE *130*2020 STRANDEN

Stranden er en horisontal overgang mellom land og vann. Der klippen danner en cæsur i terrenget, et sted hvor landet ikke kommuniserer med vannet, er stranden en glidende overgang mellom terra firma og sjøvannet. Dansk skiller mellom forstrand og strand, norsk mellom fjære og strand, for å sondre mellom området som jevnlig oversvømmes, og det som unntaksvis dekkes av havet. Flomålet betegner det høyeste punktet vannet regelmessig når, fjæremålet det laveste. Ordet "tidevann" kopler strandkantens omskiftelige karakter eksplisitt med tiden og med vannet, slik som "fjære" betegner både et rom og en tidsperiode. Å snakke om stranden i entall er derfor en abstraksjon, en idealitet konstruert på grunnlag av fysiske fellestrekk og de aktiviteter disse muliggjør. Fra naturens side er de fysisk forskjellige og kan bestå av sandkorn, skjellsand, grus, småstein og svaberg, ingen strender er like.

Manchester-by-the-Sea i Massachusetts, USA, er kjent for sin syngende strand, omtalt som The Singing Beach eller The Singing Sands. Stranden endrer også farge med lysforholdene. Det samme audiovisuelle fenomenet forekommer også langs Rødehavet (Lenček og Bosker 9). Besjelende navn som The Singing Beach eller The Singing Sands viser hvordan den kulturelle bearbeidelsen gir et gitt terreng identitet og eksistens gjennom å etablere den som et objekt ved å beskrive, avgrense og utforske. "Stranden" finnes således ikke, kun i reiselivets feriekataloger er den ene stranden til forveksling lik den neste, et rent kulturprodukt.

Sandstrender har en god del til felles med ørkener. På tross av nærheten til vannet er de livløse og ugjestmilde på et vis som står i kontrast til aktivitetene som utspiller seg der. Lite, om noe vokser på dem; de tilhører en annen temporal orden enn den menneskelige. Sandkornene kan være milliarder av år, og hvite sandstrender bestå av kalkrestene av utdødde livsformer. Slik er de arkiver for en dyp tid som overskrider et antropologisk og historisk perspektiv. Men selv om sandstrandens geologiske tid synes å unndra seg enhver kultur, er den eminent kulturell, og ikke bare i etnografisk forstand: Takket være masseturismen eksisterer dagens viktigste badestrender kun i kraft av at de vedlikeholdes ved hjelp av importert sand og mudring (Gillis 149).

Antropologer og kulturforskere fremhever gjerne hvordan strandens nærhet til det utenfor, dens karakter av randsone, gjør den til et utsatt 


\section{KNUT OVE ELIASSEN \\ STRANDENS TOPOLOGIER}

rom, uavklart, og derfor ofte underkastet egne regler. Grenser uttrykker og markerer overganger mellom forskjellige ordener, for eksempel politiske, ontologiske eller epistemologiske. De er derfor i prinsippet fenomener av annen orden ettersom de er betinget av andre realiteter for å eksistere samtidig som de regulerer relasjonene mellom disse. Fysiske strender er sammensatte objekter, de finnes ikke uavhengige menneskelig praksis og erkjennelse. Med Bruno Latours term kan de kalles "kvasi-objekter", ting som på samme tid er umenneskelige og menneskelige, natur og kultur (Latour 73).

Antropologen Tim Ingold insisterer på at strender er taskscapes, og at deres egenskaper, praktiske realiteter, trer frem i bruken av dem (190). De er steder for sanking og fiske eller markeder og havner; den bygde havnen, the port, er relativt ny, i eldre tider strandet man båtene. De historiske praksisenes mangfold artikuleres diskursivt i strandrettens tekniske definisjoner som bestemmer strandens juridiske realitet - som marbakken, strandkanten, forstranden, etc. - og hvem som har retten til å utnytte den. Også vitenskapens blikk er analytisk og taksonomisk og skiller mellom strender med henblikk på morfologi og biotoper. Hva romantikkens stormfulle kyster angår, forutsetter estetiseringen av naturen, som Adorno gjerne påpekte, naturbeherskelse, penger og fritid (Adorno). Byrons berømte feiring av havet med linjer som "Roll on thou deep and dark blue Ocean" fra Child Harold's Pilgrimage (1812-1818) er lystyachteierens perspektiv, ikke kystfiskernes praktiske realitet. Når hollandske malere som Jan van Goyen, Simon de Vlieger, og Willem van der Velde "oppdager" strender som Scheveningen som motiv på 1600-tallet, er det som landingsplasser for skip, og scener for dagligliv og yrkesaktiviteter (Giltaij og Keltch).

To hundre år senere, takket bærbare staffelier, tinntubemaling og jernbanen, kunne strandlivets lys- og fargespill gjøres til gjenstand for impresjonistenes systematiske studier som dermed kunne gi det parisiske publikum de første forlokkende bildene av ubekymret borgerlig badeliv. Naturbeherskelsen muliggjør slik de estetiske sjablongene som satte premissene for masseturismen (Lenček og Bosker 127). Deres innbyrdes forskjeller til tross, alle disse måtene å bruke og å tematisere stranden på - juss, vitenskap, kunst, litteratur og turisme - deltar på tvers av sym- 


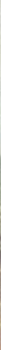

Fig. 2. Adriaen van de Velde: Het Strand van Scheveningen (1658). Olje på lerret (50 x 74). Museumslandschaft Hessen Kassel, public domain.

boliseringssystemenes særlige rasjonaliteter i en større historisk diskurs hvor stranden opparbeides, forhandles og behandles. Verdiene knyttet til strandtopoiene får dermed konkrete følger for hvordan strendene forvaltes.

Strendenes forskjellige artikulasjoner som taskscapes kan også etterspores i ordforrådet europeiske språk stiller til rådighet for å betegne sonen mellom fast land og omskiftelig hav. Beach, shore, littoral, strand eller the seaside, er ikke synonymer; de betoner forskjellige fysiske former og forskjellige bruksmåter, altså forskjellige realiteter. Det samme gjør franske termer som rivage, rivière, plage, greve og estran. Grève betegner således en strand velegnet til å trekke opp skip, men samtidig også grusen den består av (grèvier). Strender er slik både fysisk realitet og kulturlandskap. Karakterisert med den tyske biologen Jakob von Üxkulls termer er de både Umgebung og Umwelt, både et gitt og et produsert grensesnitt til den fysiske verden. Som strender er de således unike antropogene realiteter: Om tangloppen er for- 
trolig med sin biotop, er den lykkelig uvitende om at den bebor en strand. Like fullt har den økologiske diskursen bidratt til at stranden er i ferd med å flyttes fra frihetens rike tilbake til nødvendighetens; som åsted for forurensingsproblemer har den uvegerlig rykket nærmere våre livsbetingelser.

\section{VED LOVENS RAND}

Stranden endrer seg med tidevannet, den er derfor vanskelig å besitte. Det gjør strandsonen til en sivilrettslig utfordring. I en studie av piratvesenets politiske historie, The Enemy of All, Piracy and the Law of Nations drøfter litteraturviteren Daniel Heller-Roazen romerrettens forståelse av forholdet mellom eiendomsrett og strandsoner og dens betydning for senere juridiske tradisjon. Romersk lovgivning utmerker seg ved sitt fokus på eiendomsrettens grunnleggende element, "tingen" (res). En ting har bestand og grenser og kan derfor defineres og eies. Land er eiendom fordi det kan gjøres til en ting, tas i besittelse, gjerdes inn og ikke minst forsvares (HellerRoazen 59-61). Selv om tidevannet er mindre markant i Middelhavet, kjente romerne godt problemet med strandens skiftende størrelse. Den generelle holdningen var, ifølge Heller-Roazen, at stranden i prinsippet falt inn under allmennretten, jus communis, men hvor havner, brygger og bygninger utgjorde unntak. Siden disse var konstruksjoner, og altså ting, kunne de lovreguleres, og stedet de sto på, besittes. Juridisk får stranden slik en usikker realitet mellom det som finnes, og det som kan besittes, som er lite forenlig med prinsippet om nomos - innhegne, besitte, bestyre - som ifølge Carl Schmitt står sentralt i europeisk rettstenkning (Schmitt). Dette er vel å merke selv om stranden i den germanske rettstradisjonen faller inn under allmennretten og altså regnes som allmenning.

Etter at Hugo Grotius' prinsipper i Mare Liberum (1612) gradvis vant frem, ble det åpne hav betraktet som en allmenning uten fellesskap hinsides den territoriale loven fordi det ikke lot seg besitte. Det juridiske ordskiftet som etterfulgte Grotius' intervensjon, reaktualiserte den gamle romerske sondringen mellom dominium og imperium, mellom besittelse og kontroll. Men om tidevannets realiteter gjør strandsonen til en utfordring for eiendomsrettens prinsipper (domus), kan den derimot beherskes, underlegges 
188 KULTUR \& KLASSE *130*2020 STRANDEN

suverenens makt (imperium) som av den grunn også har rett til å tildele "forstrandsrettigheter" som Christian Vs lov sier det i 1684 .

Et iøynefallende uttrykk for imperium er at stranden fungerte som rettersted for havets fredløse, piratene. Den såkalte Execution Dock ved Themsens utløp i Wapping tjente i fire hundre år som rettersted. Her ble galgene reist mellom lavvanns- og høyvannsmerket, og de avstraffede ble ikke tatt ned før tidevannet hadde overskylt dem tre ganger (Jowell 41). I lovens randsone er stranden et område hvor det blir desto viktigere å vise maktens nærvær ved å sette i scene "straffens teater", for å låne Michel Foucaults term fra Surveiller et punir (108). At det handler om sjørøvere, tydeliggjør strandens porøsitet som grense betraktet. For sjørøveri er intet rent maritimt anliggende, "sjøens folk", som de gjerne omtalte seg, levde utenfor loven, men drev sin virksomhet på land som til havs. Strandhogg for å skaffe slaver til slavemarkedene i Nord-Afrika var en etablert inntektskilde lenge før slaveskipene begynte å seile på Amerika.

Kystlinjer er porøse, og horisonten er et kontingensens sted. Stranden er dermed et grensesnitt og en kontaktflate, et rom for ønsket så vel som uønsket kontakt med fremmede. Selv hos de sjøfarende grekere var den fremmede fra sjøen en tvetydig figur. Da Telemachos tas imot av Nestor, utspørres han utfordrende: "Strangers, Who are you? Whence do you sail over watery ways? Is it on some business, or do you wander at random over the sea, as pirates do, who wander hazarding their lives and bringing evil to men of other lands?" (III, 71-74) Kyklopen gjentar formelen overfor Odysseus. Den fremmede, xenos, er out-of-place og er både en mulighet og en trussel. Herodot og Thukydid lar Hellas' historie ta til med strandhogg, slavejegere og pirater (Herodot 2, Thukydid 4). Nye territorier tas i besittelse fra stranden. Iliaden utspiller seg på Trojas strand, og hos Vergil brennes Aeneas' skip ved ankomsten til Latium (5, 603).

Men strender har ikke kun vært åsted for strid. Som noe som ikke kan besittes, kan de sies å tilhøre alle og dermed være et sted for fredelige møter. I frihavner som grekernes emporion fikk reisende trygt trekke opp

3 Jeg siterer fra engelsk da verken fremmede og sjørøvere av rytmehensyn finnes i Peter Østbyes norske oversettelse av Odysséen. 
båtene, selge eller bytte varer. Som frihavner var de underlagt egne lover, og adgangen til dem over land var regulert. Men derfor ble strandsonen avsperret, ikke bare i emporia, men også i romernes portus, arabernes funduq eller merkantilismens factory.

For skepsisen overfor reisende er ofte stor. Ikke nødvendigvis fordi de kom med onde hensikter, men fordi kontakt med det fremmede, det oversjøiske og ikke minst det omflakkende representerte en fare for kulturell smitte. Platon og Cicero var ikke de eneste som argumenterte for at byer burde anlegges langt fra kysten for å unngå moralsk kontaminasjon fra tilreisende. Et svært håndfast uttrykk for bevisstheten om de strategiske konsekvensene av strandens porøse karakter er andre verdenskrigs tyske bunkerarkitektur. Der Altantikwall strekker seg i en nesten ubrutt linje langs Europakysten fra Biscaya-bukten til Nordishavet. Om dette tidlige forsøk på å bygge en moderne strandmur var rettet mot en invasjon fra vest, er Europas nyeste defensive strandlinje rettet mot sør, anlagt i en fremskutt posisjon fra strendene den forsvarer. Emigrantene skal stoppes før de når frem til Solkysten eller Lampedusa. Immateriell og elektronisk bruker European border Surveillance system, EUROSUR, EUs overvåkningssystem droner, offshore sensorer, rekognoseringsfly og satellittovervåkning for å stoppe uønsket immigrasjon fra Afrika.

\section{DEN FRIE TIDENS STRAND}

Sun and Sea (Marina) tar utgangspunkt i stranden som en moderne versjon av det gamle toposet locus amoenus, det behagelige stedet. Operaens sceniske uttrykk preges av et tyvetalls badegjester på en sandstrand, alene eller i par, vennegrupper, familier og barn, til og med et par hunder, alle opptatt med ferielivets formålsløse fritidsaktiviteter. Det umiddelbare budskapet er liketil nok, vi befinner oss i en klimakrise; den globale appetitten etter strandliv er en del av årsaken, samtidig er stranden også et sted hvor krisens symptomer lar seg registrere, forsøpling, forurensing, ødeleggelse av biotoper, algeinvasjoner, forsuring, etc.

I reisebyråenes reklamer er stranden et topos i termens tradisjonelle forstand, et allmennsted som rommer et visst antall komponenter, vann, 


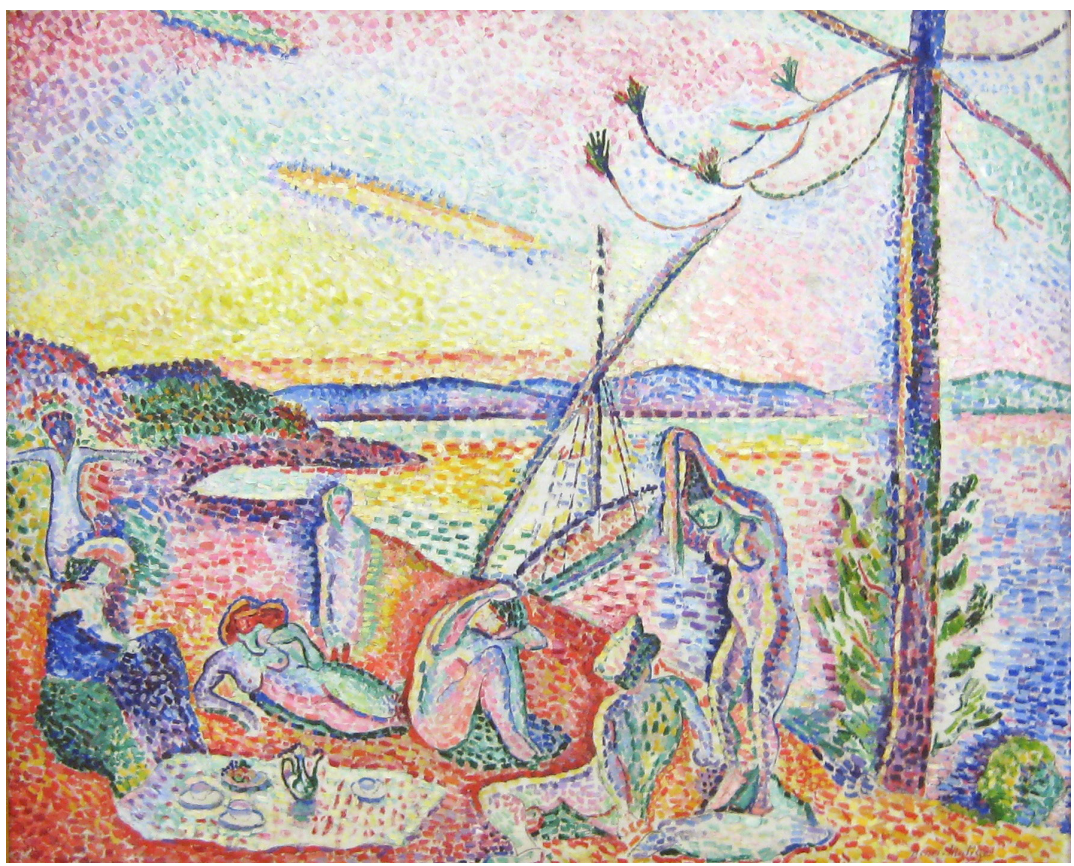

Fig. 3. Henri Matisse : Luxe, calme et volupté (1904). Olje på lerret (98,5 X 118,5). Musée d'Orsay. Paris, public domain.

skygge, varme, sand, renhet etc., og som dermed også signaliserer en rekke mulige handlinger, litteraturvitenskapelig uttrykt, plots, i betydningen "dette kan jeg gjøre": soling, svømming, surfing, lek, ekshibisjonisme, uteliv etc. Det er her tale om en bestemt estetikk hvor idealstranden slik den markedsføres, har lite å gjøre med reelle badestrender, strendene er folketomme, restaurantbordene ubesatte, solstolene ledige osv. Kort sagt, "Là, tout n'est qu'ordre et beauté / luxe, calme et volupté" (Der finnes det kun orden og skjønnhet / luksus, ro og sanselighet), som det heter hos Charles Baudelaire i 1856. Som betegnelse på strandliv hører dog luxe, calme et volupté det tyvende århundret til og har mer til felles med Henri Matisses fauvistiske pionerarbeid fra 1904 med samme tittel - badende nakne kvinner på en strand i Saint-Tropez - enn med Baudelaires dikt "L'Invitation au voyage". 
Stranden hadde gradvis blitt et sted for bading og restitusjon mot slutten av 1700-tallet. Ofte trekker man frem de engelske badekurene og det fenomen som rundt Napoleonskrigene fikk navnet The English seaside. Men det attende århundrets terapeutiske bading og helsebringende sjøluft har lite å gjøre med sydenferiens solkultus (Lenček og Bosker 73). Svømming og solbad er aktiviteter som sprang ut av kropps- og sunnhetsidealene til den vitalistiske kroppskulturen som vokser frem mot slutten av 1800-tallet. Solbrun hud var ikke lenger et merke på utendørs fysisk arbeid, men et tegn for den conspicuous leisure Thorstein Veblen satte navn på. Å ligge på badestranden er beviset på at man tilhører dem som har råd til å ødsle med tiden (Veblen 38).

F. Scott Fitzgeralds roman Tender is the Night (1934) tar for seg de samme velstående amerikanerne Veblen hadde studert få år tidligere. Det var disse som rett etter første verdenskrig gjorde Middelhavet til en sommerdestinasjon. Modellen for Fitzgeralds romanhelt Dick Diver, Gerald Murphy, overtalte i 1923 eieren av Antibes' Hotel du Cap til ikke å stenge i mai, men holde åpent hele sommeren. Strålende solbrun etter et opphold ved Middelhavet ble den franske motedronningen Coco Chanel samme år solbadingens første ikon. Stranden ble et sted for kroppsbevisst velstand og ikke lenger det kursted for overvintring i trygg avstand fra storbyens uorden, stank og skadelige miasmer verselinjene fra Baudelaires dikt alluderer til.

Thomas Manns Der Tod in Venedig (1913) utspiller seg rett før den første verdenskrigen. Von Aschenbach ankommer en Lido preget av den gamle aristokratiske kurstedskulturen. Med familienes overhoder virksomme hjemme, domineres stranden av kvinner og barn; strandgjestene er godt tildekket, de svømmer ikke, men bader; de voksne promenerer, og de unge leker (461). Den klassisk skolerte protagonisten sensurerer og sublimerer gjennom klassiske forelegg sitt gryende homoerotiske begjær til den unge Tadzio. Skjønt Manns ironi er åpenbar, badende efeber - unge menn under tyve - var i annen halvdel av 1800-tallet et lett betent homoerotisk emne; europeiske malere reiste til Sør-Italia på vinterstid for å portrettere fattige, gjerne avkledde, italienske gutter.

Men om Manns langnovelle utspiller seg i verden av igår, får i ettertid dens seksuelle tema preg av å foregripe den erotiseringen av stranden 
som er åpenbar hos Matisse og Fitzgerald, og som inngår som komponent i massesamfunnets demokratiske variant av locus amoenus (vann, sol, bris, skygge, erotikk etc.). En arena for ekshibisjonisme, kontrollert nakenhet og bading, gir den anledning til kontakter av ymse slag som ikke aksepteres i det offentlige rom. Algers badestrender i Albert Camus' L'Étranger (1942) er mest kjent som åstedet for drapet av den navnløse algerieren, men den leverer også scenen for Meursault og Maries erotiske badeleker (Camus).

Som et sted for kroppseksponering, erotikk og voyeurisme adlyder badestrender andre regler enn byrommet. Her suspenderes reglene som styrer omgangen i samfunnet ellers. Slik er moderne badestrender ofte avgrenset fra rommet innenfor med en promenade, en slags grense for grensesonen, som markerer at det på den andre siden gjelder andre regler her tildekker man seg. I sin kjente artikkel om heterotopier, rom underlagt andre kutymer og tidsrytmer enn de allment gjeldende, kommer Michel Foucault inn på et sekstitallsfenomen som franske Club Meds ferielandsbyer (Le Corps 32). Få har tegnet dette universets heterotopiske karakter skarpere enn James Ballard hvis Cocaine Nights (2009) skildrer et britisk feriested på Marbella-kysten, en gated community, hvor de tilreisende får utleve sine fantasier om et slaraffenland med fritt utløp for sex, rus og umiddelbar behovstilfredsstillelse. Både Camus og Ballard har et sikkert blikk for hvordan badestrandens erotiserte sanselighetskulturer er latente med aggressivitet og vold.

\section{BEACHCOMBING}

I moderne tid har få eksistensformer funnet et fast tilholdssted på stranden, den er et sted for transitt og midlertidig opphold. Et unntak som har gjort dette stedet utenfor territorialiteten til sitt, er beachcomberen, en liminal sosial eksistens som med etnografiens termer lever in-betwixt and in-between. Rømt fra skipet var beachcomberne sivilrettslig papirløse, de kom seg i praksis ikke videre; eksistenser i limbo, overlever de på hva de finner på strendene i nærheten av havnen, eller ved å tigge av gjennomreisende sjømenn. Uten nasjon og uten papirer fant de utenfor loven en eksistens i den sosiale randsonen mellom kultur og natur, mellom det faste og det 


\section{KNUT OVE ELIASSEN \\ STRANDENS TOPOLOGIER}

flytende. Den klassiske versjonen hører til i Stillehavet og strekker seg fra sjømannen Herman Melvilles Typee til John Steinbecks beach bums i Tortilla Flat - før global havforsøpling produserte sine senmoderne inkarnasjoner i Poix' Jacob eller i vietnamesiske fiskere som etter at industritrålerne har

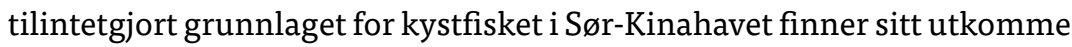
som plastsankere.

Retten til fiske, skjell- og tangsanking, berging, vrakgods og drivved, har tradisjonelt vært en rettighet for Nord-Europas kystbefolkning; stranden har vært allmenning. Samtidig har verdiene vært store nok til at retten til strandens rikdommer er det sentrale emnet i fjerde bind av Jean-Baptiste Colberts store regulering av fransk maritim lov i 1681, L'ordonnance de la marine. Den bestemmer først strandens grense med flomålet til den høyeste springfloen ved fullmåne i mars måned og fastslår deretter at le rivage er domaine public maritime, altså allemannseie (410). På lignende vis har tradisjonene for næringsaktiviteter på stranden i de fleste nord-europeiske kystnasjonene avsatt seg i strandrettens reguleringer av opphold og ferdsel på stranden og retten til å høste av havet. Den gamle normanniske betegnelse på drivgods, Varecq, betegner påfallende nok også sukkertang. Her må det også tas i betraktning at fiskeri historisk stort sett har blitt foretatt fra land eller svært kystnært, det er relativt sent fiskere våger seg ut på det åpne havet og da som følge av at de kystnære ressursene rett og slett er fisket opp (Roberts).

Strandens status som allmenning, fellesskapets eiendom, antyder at dens kulturhistorie er gammel. Dette er i The Human Shore utgangspunktet i en alternativ sivilisasjonshistorie. Snarere enn å godta kulturantropologiens etablerte narrativ om at samfunnets opprinnelse i jegerkulturer og i konkurransefortrinnet ved stammedannelser, finner Gillis et alternativ i vandringene til homo litteralis, kystens menneske (Gillis). Tanken om at det amerikanske kontinentet ble befolket av grupper med jegere som krysset over fra Asia på jakt etter storvilt, erstattes med the Kelp Road, sukkertangens vei. Strender er både fremkommelige og rike på ressurser.

Et velkjent uttrykk for at stranden er ressursenes sted, er Robinson Crusoe som etter å ha overlevd verdenslitteraturens mest berømte skipbrudd plyndrer vraket av skipet som førte ham til øya og skaffer seg det 
194 KULTUR \& KLASSE *130*2020 STRANDEN

han trenger til å påbegynne jobben med å oppbygge en livsverden. Som en av litteraturhistoriens første strandgjester tar han regelmessige pauser fra sitt daglige strev ved å promenere på stranden i tilfreds uvirksomhet, utstyrt med parasoll, strandantrekk og det britiske gentrys trofaste ledsager, hunden. Tro mot britisk tradisjon viser han seg som empiriker og gir seg $\mathrm{i}$ gang med naturhistoriske studier, tar bestikk av vær og vind, og observerer og noterer i loggboken de fenomenene som viser seg. Stranden påkaller hans interesse som amatørforsker inntil idyllen plutselig brytes med et fotavtrykk i sanden; fremmede har krenket grensen for hans verden, og bekymringsløse strandpromenader avløses av byggingen av festningsverker.

Det 21. århundrets beachcomber kommer i flere utgaver: Aner man i den tredje verdens søppelsankere den spøkelsesaktige gjenkomsten av dem som søkte strender som gavmildt gav til dem med blikk for deres skatter, finner i det rike nord materielt mer distanserte beachcombere, samlere som saumfarer strender for drivgods fra containerskip. Donovan Hohn forteller i Moby-Duck om sin jakt etter 28800 badedyr i plast fra en container som gikk over bord i Stillehavet januar 1991. Lekene, herunder 7200 gule ender, seilte de neste årene verden rundt for etter hvert å strande i California, Maine eller Shetland og fange amatørsamlernes interesse (Hohn 34).

\section{LOCUS TERRIBILIS}

Denne strandens krøniker! Hvem andre kunne skrive dem enn en forlist sjømann? Hvor mange har kun sett den midt i fare og nød, den siste stripen av land deres øyne så. Tenk på all den lidelsen en enkelt strand har vært vitne til! De gamle ville ha fremstilt den som et havmonster med åpen kjeft, langt frykteligere enn Skylla og Karybdis. (Thoreau 963)

Få linjer senere dveler teksten ved "to kropper på stranden [...], kanskje var de mann og kone, og de som Gud hadde forenet hadde ikke blitt atskilt av havet" (ibidem). Med sitt fokus på eksistensene som fant sitt utkomme ved kysten, er Henry David Thoreaus skildringer av Cape Cod fjernt fra dagens realitet; fiskere og fisk er borte, rike feriegjester har tatt plassen deres, og likene av druknede irske immigranter skylder ikke lenger opp i fjæresteinene. Med kystfiskeriets opphør, stålskrog og vanntette skott 


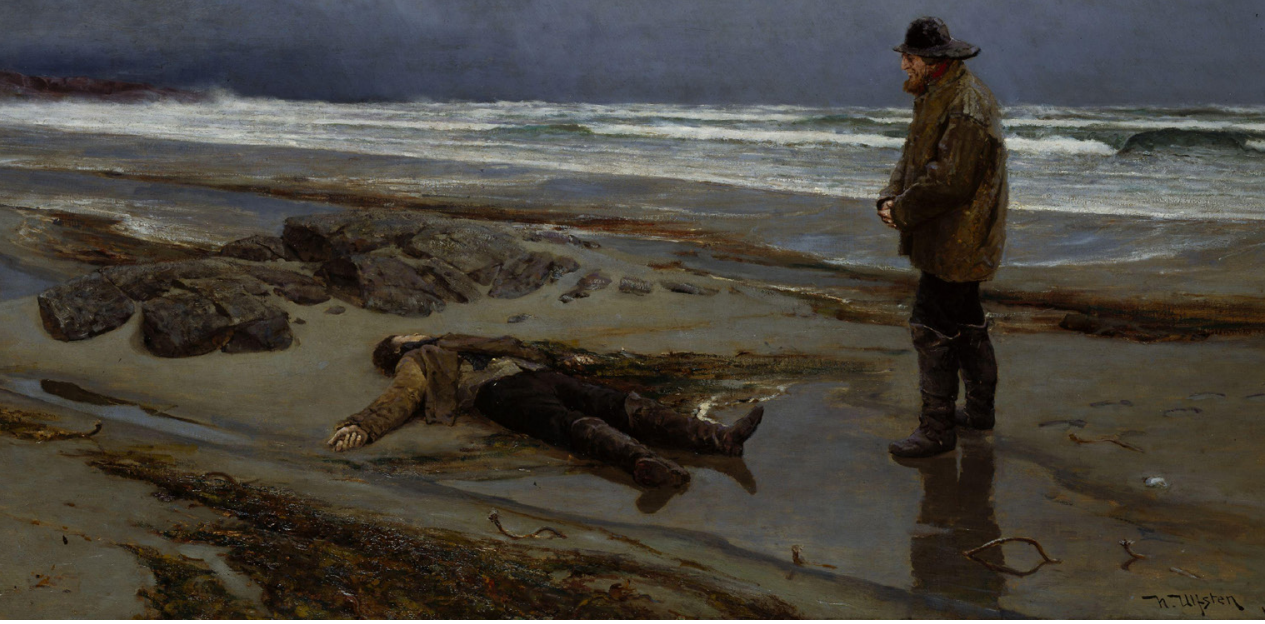

Fig. 4. Nicolai Ulfsten: En strandvasker (1884). Olje på lerret (110,5 x 182). Nasjonalmuseet for kunst, arkitektur og design. Oslo, public domain.

sluttet den druknede i vannkanten - strandvaskeren - å være et fast syn langs Nord-Atlanterens kyster, og ordet forsvant ut av bruk. Toposet er stort sett unngått i malerkunsten, med noen kjente unntak, som Nicolai Ulfstens En Strandvasker (1884). Skagen-malerne foretrekker scener som knytter de druknede til fellesskapet, Michael Anchers Den druknede (1896) ligger på bordet hjemme med de nærmeste rundt seg, mens Laurits Tuxens Den druknede bringes $i$ land (1913) viser to menn som bærer den døde gjennom brenningen. Ulfstens enslige betrakter fremhever den døde kroppens ensomhet. Toposet fikk i 2015 en dramatisk aktualisering med bildene av den tre år gamle druknede kurdiske båtflyktningen, Alan Kurdi, liggende i fjæresteinene i en tyrkisk strand. Individualiseringen av Kurdi står i en slående visuell kontrast til de bildene av tildekkede døde kropper som har ledsaget nyheter om druknede afrikanske immigranter, og som også utgjør et topos i Isaac Juliens The Leopard (Western Union Small Boats). Ansiktsløse er også Life-fotografiet fra 1943 av tre døde soldater i brenningen på Ny-Guineas Buna Beach, de første offentliggjorte bildene av falne amerikanske soldater under den andre verdenskrigen. Om representasjonen viser én eller mange 
196 KULTUR \& KLASSE *130*2020 STRANDEN

er ikke likegyldig; individualiseringen inviterer til identifisering, fotoene av de mange døde signaliserer mengde, men anonymiserer.

Stranden er stedet hvor stormene deponerer sine etterlatenskaper. Mennesker, dyr, døde fisk og diverse former for avfall, har regelmessig skyllet i land på Atlanterhavets kyster, like mange påminnelser om havets fremmedhet. Historikeren Alain Corbin innleder sin studie av strandens historie i Vesten, Le territoire du vide ('Tomhetens territorium') med å redegjøre for hvordan stranden i den kristne tradisjonen gjaldt som et heslig sted, en grensesone mot Le Grand Abyme ('Den store avgrunn'), undergangens verden og døden, blir stranden som grensen mellom hav og land et symbol både på skapelsesakten og på den guddommelige ordens grense. I havet lurer sjømonstre og flodbølger som truer demarkasjonslinjen mellom utenfor og innenfor (11).

Bibelens beretning om syndfloden leverer et avgjørende bidrag til oversvømmelsens topos, men tanken om at havet sluker landet er en straff, har også funnet sin vei inn i skriftene til mer verdslig innstilte forfattere. De greske historikerne Herodot og Thukydid kan fortelle om jordskjelv som ble etterfulgt av flodbølger og druknede byer, mye omtalte eksempler i klassisk historie er henholdsvis Potidaia (479 f.Kr.) og Malia-bukten (426 f.Kr.). Langt senere, i starten på sitt berømte essay om kannibaler, gjør Michel de Montaigne seg tanker om de skiftende sanddynene i hans hjemegner ved Atlanterhavskysten, at de sluker landsbyer, men at de også selv kan slukes av havet. Stranden blir for franskmannen et topos på tilværelsens grunnleggende ustadighet og omskiftelighet. Fabellandet Atlantis er kanskje det beste eksempelet på hvordan land er utsatt for å slukes av havet, og Corbin understreker hvordan naturhistorien helt frem til 1840 så i flodbølger og erosjon avgjørende hendelser i jordens geologiske historie (15).

Nå er stormflod og tsunami ikke bare et klassisk topos, oversvømmelser har i historisk tid vært en reell trussel i Nordsjøområdet. Karen Blixen tyr til stormflodens topos for å sette scenen for fortellinger og møter i "Syndfloden over Norderney" (1934). Utgangspunktet for Theodor Storms fortelling, "Der Schimmelreiter" (1888) er Frislands dikegrever, utpekt til å holde overoppsyn med dikene. Emmanuel Carrère i D'autres vies que la mienne (2009) lar tsunamien i det indiske hav i 2004 stå sentralt i en studie 


\section{KNUT OVE ELIASSEN \\ STRANDENS TOPOLOGIER}

av liv hvis livstråder brytes. Men at havet bryter inn og sluker landet, fremstår idag i mindre grad som naturens lunefulle innfall eller uttrykk for en ukjent skjebne, snarere uttrykker de en antropogen realitet. Den globale oppvarmingen innebærer en reell og overhengende fare for Stillehavets øysamfunn - øyer hvis sandstrender langt på vei er kanskje det reneste ideologiske uttrykket for forestillingen om et bekymringsløst strandliv.

Strandtoposet 'katastrofens sted' påminner om at katastrofer alltid er noens eller noes, deres katastrofiske realitet er kontekstbetinget (Eliassen). Derfor kan de være tvetydige, eller snarere, ha en dobbeltkarakter. Slik betegnet katastrofen i den aristoteliske poetikken omslagets øyeblikk, om undergangen er en avslutning, rydder den også plass for nye begynnelser. Om stranden er åsted for havarier, for undergang og drukningsdød, kan den også være et redningens sted. Etter å ha forlist redder Odyssevs seg naken i land på Scheria (Korfu), ber om hjelp og tas hånd om, kles og mates av fajakernes prinsesse Nausikaa og hennes tjenestepiker, og tilbys hjelp.

\section{THE BEAUTY AND THE BEACH}

Når stranden faller inn under det naturskjønnes estetikk, er det som et paradigmatisk eksempel på skjønnhetserfaringens historiske karakter. I innledningen til Voyage en Hollande nedtegnet under hans opphold i landet i 1773 og 1774, dveler Denis Diderot ved reisen langs kysten fra Haag til Amsterdam. Veien er anlagt på toppen av dikene, skriver han, på den ene siden havet, nærmest kant $\mathrm{i}$ kant med veien, på den andre siden, betydelig nedsenket, dyrket land. "Dette sceneriet vil få Dem til å drømme og skjelve" (Voyage 51). Skuet av havet holdt tilbake av menneskeskapte konstruksjoner er rett og slett sublimt. Diderot vier i delen om hollandske byer et helt kapittel til byen Scheveningen, allerede et kjent utfartsmål for både dikene og sjølandskapet (Corbin 45-46).

Der kunne jeg se den uklare horisontlinjen, havet sløret av tåke, de urolige bølgene; i det fjerne de store seilskipene, og foran dem fattigslige fiskekuttere mellom to bølger; i strandkanten, skjelvende av kulde og frykt, søkte et stort antall kvinner varme i solen. Vinter eller vår, uansett årstid var Scheveningen [o.a. Diderot skriver Scheveling] min favorittpromenade. (Voyage 171) 
198 KULTUR \& KLASSE *130*2020 STRANDEN

Opprinnelig fra landbruksbyen Langres var Diderot lite bereist og uten erfaring med havet; hans viten stammet fra litteraturen og malerkunsten, den hadde lært ham å se. Maritime landskap var han primært fortrolig med fra sine besøk til de franske salongene fra 1759 til 1771. Således heter det i Salongen av 1767: "Om de hadde besøkt kunstneren litt hyppigere, ville han kanskje ha lært Dem å se dét i naturen, som De ikke kan se" (Salonerne 123). Den siterte passasjen fra Voyage er et godt eksempel på dette, et maritimt perspektiv med bakgrunn, mellomgrunn og forgrunn.

I Diderots maritime estetikk møtes to forskjellige og delvis divergerende impulser, det skjønne og det sublime: Mens det sublime, havets tøylesløse og skrekkinnjagende kraft, blir det romantiske topos par excellence, faller badestrandens estetikk inn under skjønnhetsestetikken. 1700-tallet oppfinner stranden som et pittoresk landskap med krav på den ensomme vandrerens interesse; her skal han iaktta og meditere over strandlinjens omskiftelige skue, bølgenes spill og farger, brenningen og lysets reflekser på den våte stranden. Eller med William Gilpins ord fra Observations, on the Coasts of Hampshire, Sussex, and Kent, relative chiefly to Picturesque Beauty made in the summer of the year 1774: "De lysende fargetonene som uopphørlig leker på det rolige havets overflate [...], marine farger som vedvarende veksler og glir over i hverandre" (4). Det pittoreskes førende teoretiker Gilpin fremhever tilstedeværelsen av "fyrtårn - fjerne byer - tårn - havner" som nødvendige rekvisitter i et behagelig skue (3). Det litt kinkige spørsmålet om hvilket perspektiv som er det beste, strandkantens eller høydens, besvares litt nølende med høyden, ettersom den gir overblikk. Ikke minst fordi det pittoreskes estetikk gjerne involverer bruken av det svært populære 'Claude-glasset' - oppkalt etter dets oppfinner, maleren Claude Lorraine - et lite og portabelt optisk redskap bestående av et lett farvet konvekst speil som tillot et innrammet og indirekte blikk på utsnitt av landskapet, men som samtidig krevde at brukeren vendte ryggen til objektet. Stranden medieres estetisk til tablå med hverdagslige aktiviteter. Det fysiske strevet med å dra opp båter, bringe inn fangsten, transportere folk og fe blir rustikke sceniske elementer. Fiskeselgere og agnsankere blir dekor i J.M.W. Turners og John Constables skildringer av strandlandskap og badebyer med ferierende byborgere (Riding og Jones 158). 


\section{KNUT OVE ELIASSEN STRANDENS TOPOLOGIER}

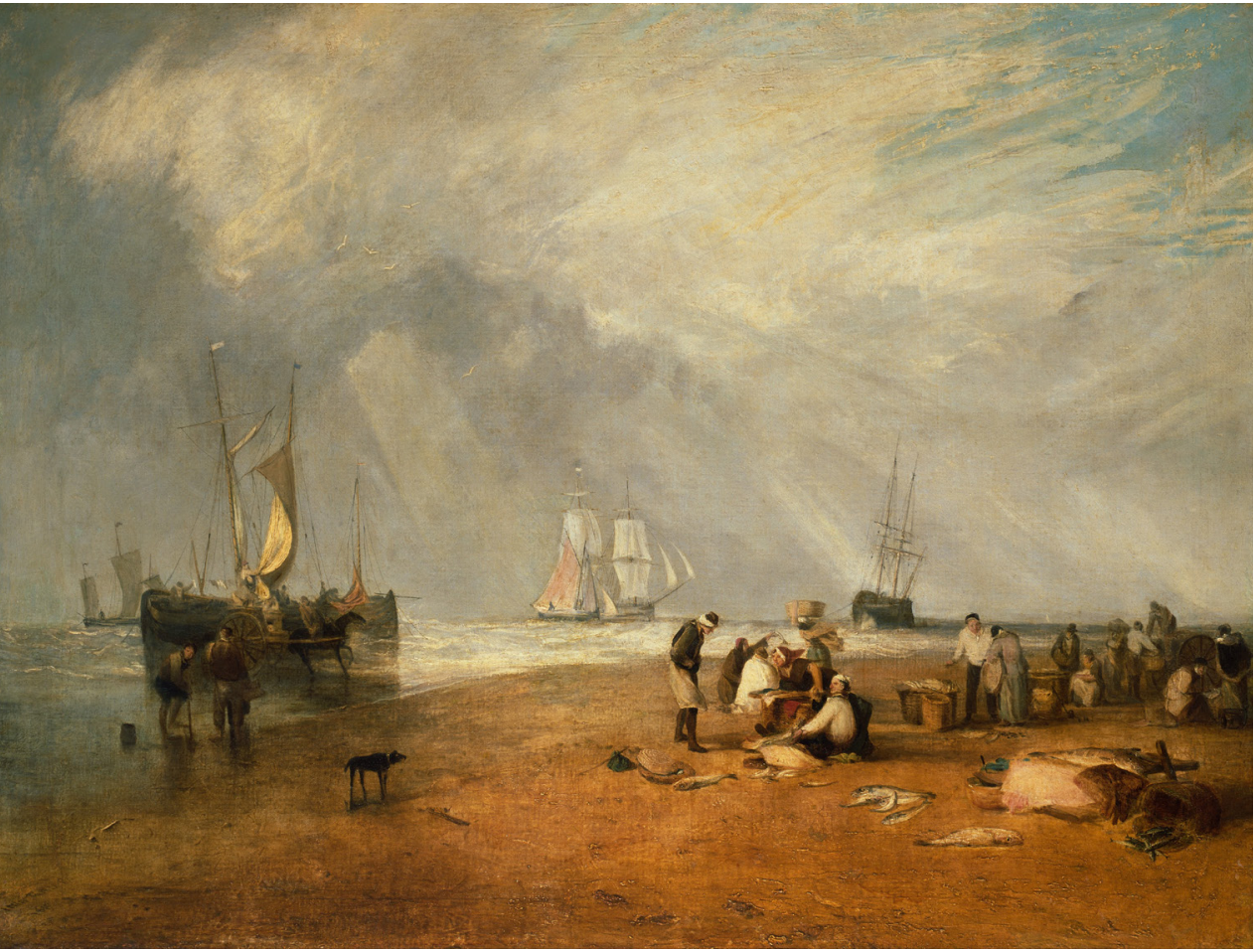

Fig. 5. Joseph Mallord William Turner: The Fish Market at Hastings Beach (1810). Olje på lerret (90,8 x 120,7), Nelson-Atkins Museum of Art, Kansas City, public domain.

"Kan De huske," sa han, "Scotts skjønne vers om havet? Åh! For en skildring de gir! De er aldri ute av mine tanker når jeg spaserer her. Den mann som evner å lese dem uten å bli rørt må ha en drapsmanns nerver. Himmelen forby at jeg møtte et slikt menneske ubevæpnet." "Hvilken skildring mener De?" spurte Charlotte. "Jeg husker for øyeblikket intet om havet i noen av Scotts dikt" "Gjør De virkelig ikke det? Heller ikke jeg klarer helt å minnes begynnelsen nå." (Austen 43)

I utdraget fra den uavsluttede baderesortromanen Sanditon (1817) utstiller Austens ironi treffsikkert de litterære topoienes estetiske begrensninger. 
Siden topoi nødvendigvis er siterbare, de er bestemt av usus, slår de hurtig over i klisjeer. Da fremstår de ikke bare uten estetisk kraft, men som sosiale sjablonger og primært som karakteristikk av personene som anvender dem.

Austens roman utspiller seg i et univers hvor overklassens valfart til badebyer er en for lengst veletablert engelsk praksis. Den franske revolusjonen og Napoleons-krigene hadde i flere tiår gjort det vanskelig å for rike briter å feriere på kontinentet. Dette hadde ført til en boom i engelske feriesteder, og Austens Mr. Parker er slik en tidlig versjon av Fitzgeralds Dick Diver; han er en ferieentreprenør og prosjektmaker fra middelstanden som setter alt inn på å få etablert en ny badeby, Sanditon. "Det var hans gullgruve, hans lotto, hans investering og hans kjepphest; hans arbeid, hans håp og hans framtidsutsikt" (13). Parkers drømte badeby er i tråd både med tidens helseråd og dens estetikk: "Kombinasjonen sjøluft og sjøbad kunne knapt nok feile, de var hver for seg alene en kur mot hva slags lidelse det nå måtte være, om det gjaldt magen, lungene eller blodet. De hjalp mot kramper, pustebesvær, sepsis, kvalme og reumatisme" (13). I tråd med førende britiske arkitekter som Humphrey Repton og John Nash som fra 1790-tallet av omsatte Gilpins pittoreske ideer i praksis (Lenček \& Bosker 90), sørger Parker for at de nybygde feriehusene anlegges fritt på en høyde med utsikt over havet, åpent med tilgang på luft og lys.

\section{DEN ANTROPOGENE STRANDEN}

Dønningen ruller innover, en stor ensom bølge, til den slår mot stranden; og der hvor det virket som det bare var sand, småstein, alger og ørsmå konkylieskjell, åpenbares det nå, når vannet trekker seg tilbake, en rand bestrødd med bokser, ferskenkjerner, kondomer, død fisk, plastflasker, ødelagte sandaler, sprøyter, greiner svarte av oljesøl.

Også han blir løftet opp av bølgen fra motorbåten, revet med av sjøen med avfall, og Palomar føler seg plutselig som en vrakrest blant vrakrester, et lik rullet opp på kirkegårds-kontinenters søppelplass-strender. Hvis intet øye uten de dødes glassaktige kunne åpne seg på jordklodens overflate ville ikke lenger [solens sverdformede reflekser på vannet] kunne stråle med sin glans. (Calvino 19-20)

Calvinos helt, Palomar, er en senmoderne utforsker av strandlivets egenart og naturestetikk, om det nå dreier seg om bølgenes egenart, den offentlige 
avkledde kroppen og blikkets regler, eller svømming, sandstrandens og lysspillets estetikk. Hans forsøk på å gripe og fastholde strandens særlige naturlighet bryter gjennomgående sammen samtidig som han i passasjen overfor lykkes med å sammenfatte både mange av strandlivets komponenter så vel som truslene det står overfor. Palomar må fastslå at lysrefleksene han i lang tid har forsøk å holde fast, kun finnes i hans blikk.

Om strandens skjønnhet er en flyktig menneskelig projeksjon, besitter menneskeskapt forurensning fysisk realitet. Skjønnhetens efemere karakter og avfallets substansialitet er imidlertid begge av antropogen opprinnelse, om enn de utspiller seg i to forskjellige registre. På stranden møtes dermed to former for temporaliteter, kulturens hurtige tid og geologiens langsomme. Denne komplekse og vanskelige håndterbar relasjonen samles i det paradoksale begrepet antropocen, den kontra-intuitive ideen om en geologisk menneskelig tid. Dette bringer oss tilbake til Latours begrep om kvasi-objekter, ting som på samme tid er menneskelige og umenneskelige, på samme tid tilhørende både naturens og kulturens landskap, og som gjør at Üxkulls skille mellom Umgebung og Umwelt ikke lenger fremstår som like selvsagt. Dagens realitet er at verdenshavenes strender overskylles av drivgods, plastavfall og oljesøl, forsuringen av vannet utløser algeoppblomstring og manetinvasjoner, og turisttrafikken fører til erosjon av strandsoner med ledsagende følger for økosystemene. Nå er det verken stranden eller havet som står overfor den mest presserende faren. Rachel Carson avslutter i 1961 forordet til The Sea around Us med ordene: "Det er en underlig situasjon at det havet hvor livet en gang oppsto, nå skulle være truet av aktivitetene til en av formene dette livet har tatt. For havet, om enn endret på dystert vis, vil fortsatt finnes; trusselen er snarere mot livet selv" (The Sea around Us xiii).

Strender er fysiske realiteter som lever sitt eget langsomme geologiske liv. De tilhører klodens dype tid; det er slik paradoksalt at det er kultusen av stranden som et sted utenfor tiden som truer med å tilintetgjøre den, i det minste innenfor den geologiske tidslommen som er arten homo sapiens'. Samtidig er strender påminnelser om de trusler karbonbaserte livsformer som vår egen står overfor. Nå er det riktignok en lang tradisjon i vesten for å bruke stranden som et topos for ødeleggelse og endelighet; 


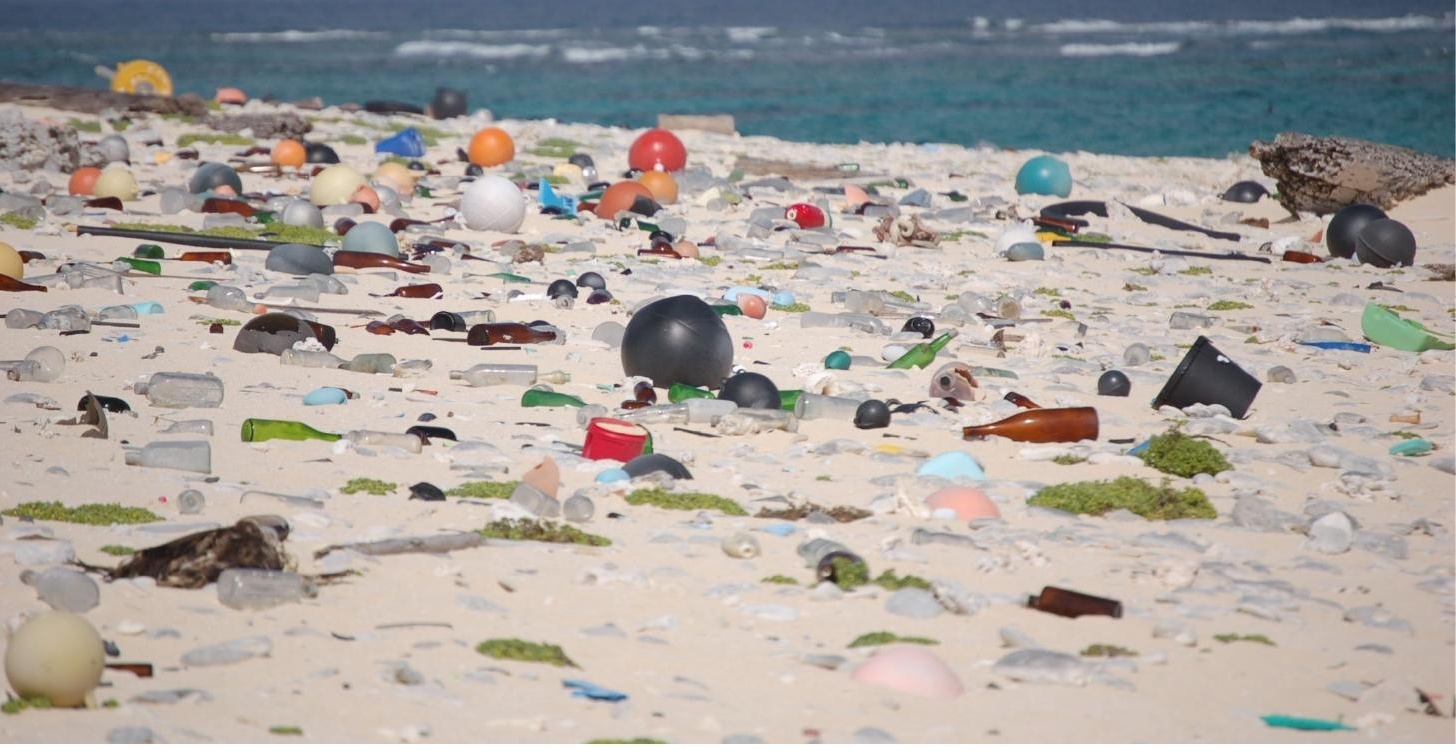

Fig. 6. Den antropocene stranden: Laysan Island i Hawaiian Islands National Wildlife Refuge, The U.S. Fish and Wildlife Service, 2009, public domain.

i den gamle kristne tradisjonen var den et sted hinsides kulturen, verken beboelig eller kultiverbar, et sted for ondskap eller for dem som har meldt seg ut av samfunnet. Som topos betraktet er imidlertid stranden betydelig mer kompleks enn kun en ødeleggelsens eller ørkenens figur. Den estetiske kraften i Calvinos skildring av den forsøplede stranden er et vitnesbyrd om hvordan stranden og estetikken har kommet sammen i ett topos.

Den topologiske analysen av strandens mange estetiske artikulasjoner er et effektivt redskap til å demonstrere strandlandskapets eminent historiske karakter. Det ligger i toposlærens vesen at topoienes semantiske til enhver tid aktuelle verdier er resultatet av de serier som bruken holder ved like, om det er diskursivt eller visuelt. Om topoi riktignok alltid forhandles, er seriene imidlertid ikke uendelig fleksible, det er et element av irreversibilitet i rekken. Gjennom usus sedimenteres betydningssjikt som trekkes med i den senere bruken. Slik har velferdssamfunnets massekultur forvandlet stranden fra et dødens sted til det motsatte, et rom for 
helsebringende og livsbekreftende aktiviteter, om det er bad, svømming, strandsport eller erotikk. Sjøluft og lukten av saltvann og tang har levert sanselige stimuli som har bidratt $i$ konstruksjonen av strender som "andre steder", heterotopier med andre regler enn verden på den andre siden av strandpromenaden. Men mens høyborgerskapets måte å forholde seg til de sanselige stimuliene på, var preget av distanse og desinteresse, preges det tyvende århundrets strandkultur av hedonisme og erotikk. For soltilbederen kjenner kun moderasjon som solbrenthetens farer, eller som det heter i Tender is the Night: "The hotel and its bright tan prayer rug of a beach were one." (Fitzgerald 5)

\section{EN KONFLIKTARENA}

Den moderne badestranden henter sin tiltrekningskraft og sosiale verdi fra ørkesløsheten.Skillet mellom fri tid og arbeid er badestrandens viktigste sosiale distinksjon. Avkledningen som utgjør det viktigste symbolske adgangsritualet til dens sosiale fellesskap, rommer et klart moment av egalitarisme; hos solbaderne er skillet mellom fattige og rike mindre viktig. Om strandkulturens erotiske momenter gjør sitt til å betone skillet mellom unge og gamle, er det like fullt ikke ekskluderende. Den sentrale distinksjonen går mellom de avkledde strandgjestene og dens påkledde arbeidere, selgere og søppelryddere, de som finner sitt utkomme på badestranden. Dette sjøkantens proletariat er en påminnelse om en tid hvor strender var en kilde til et utkomme, og da ikke kun som et sted for tjenesteytende arbeid, men også for primærnæring.

Det var jernbanene som fra midten av det nittende århundret slapp til massene til de britiske badebyene. Bath, Blackpool og Brighton ble overtatt av middelklassen, og etter hvert arbeiderklassen, mens samfunnets toneangivende klasser migrerte til private strender eller til fjernere kyster. Hermed kunne stranden bli et bakteppe for sanselige gleder, voyeurisme og seksualitet, drivkraften i TV-produkter fra Love Island til Jersey Shore og Ex on the Beach. Derfor er volden heller ikke fraværende, et berømt pop-kulturelt eksempel er slaget mellom "mods and rockers" på Brighton Beach i 1964 som står sentralt i The Whos rockeopera og senere film Quadrophenia. 
204 KULTUR \& KLASSE $* 130 * 2020$ STRANDEN

Strandens historie er slik også innskrevet i klassekonfliktenes historie. I takt med at stranden demokratiseres, rykker de rike ut til stadig mer isolerte og eksklusive badesteder, mens de lavere lagene tar over. Slik frimurertradisjonen krevde at medlemmene som opptas legger av seg sine borgerlige attributter ved døren og trer avkledd inn i ordenen av likemenn, har strandens avkleddhet en viss demokratiserende kraft. Like fullt har strendene alltid hatt et klassehierarki mellom de arbeidende og de arbeidsfri. På 1700- og 1800-tallet var de førstnevnte fiskere og sankere, i dag er det selgere og renholdspersonale; som strandens scenearbeidere er de påkledd firmaklær for å holde dem atskilt fra dem som er der for å ødsle av sin frie tid.

Om påkledningene gir servicepersonalet et visst preg av fremmedelement, er de flyktende immigrantene et entydig eksempel på dette. De er matter out-of-place som brutalt demonstrerer nord-/sør-problematikken i de økonomiske realitetene som ligger til grunn for ferieparadisene, hvor demokratiske de enn måtte fremstå. Den gangen New Yorks berømte og beryktede city commissioner Robert Moses i sin tid planla veisystemet som forbedret den jevne befolkningens adgang til Long Islands strender, ble broene systematisk anlagt for lave til at busser kunne passere, for slik å holde byens fattige, i all hovedsak svarte innbyggere, vekk (Berman 299).

Det som bestemmer strandens topologiske realitet per det enogtyvende århundre, er dens politiske aktualitet, geopolitisk, økonomisk og $ø$ kologisk. Strandtopoiene leverer analytiske nøkler til å dechiffrere den europeiske strandens komplekse historie, men også til å vinne nødvendig distanse til den patos de mobiliserer når de sirkulerer i de forskjellige offentlige rom. Strender er estetiske skuer, sosiale arenaer, økonomiske ressurser, og transittmedier. Bokstavelig talt en marginal realitet er "stranden" også et rom for kontakt og konflikt. Om badegjesten suspenderer reglene for den gitte sosiale orden, er strandlivets karakter av unntak, av fri tid og et annet liv, ikke primært en utopi, men bekreftelse av at den herskende ordens realitetsprinsipp råder utenfor.

Allikevel lar ikke stranden seg restløst innskrive i en herredømmets logikk. I egenskap av grensesone er den ambivalent, betinget av de to elementer den markerer overgang mellom. Havet er både det sted arten har sitt 
opphav, og det sted den ikke kan vende tilbake til for å bebo. Overgangen til landfast eksistens er overgangen fra prehistorien til historien. Kultur bygges på landjorden. To klassiske greske figurer symboliserer dette, Afrodite og Odyssevs. Afrodites fødsel i de skummende bølgene ved Kythera, kjærlighetens øy, begynner verden i strandsonen, Odyssevs den havarerte fremmede mottas i land i henhold til gjestevennskapets lover. Den ene kommer med løfter om sanselige gleder, den andre er en fortvilet havarist som ber om hjelp.

Da Curtius resymerte kategorien locus amoenus, var det som idealisert sted, et bukolisk sted for bekymringsløshet, gjerne med lett erotiske overtoner. Locus terribilis, det forferdelige stedet, er dets motstykke. I strandens kulturhistorie er de to komplementære, stranden kan både være et hvilested for nytelse og sorgløshet, og den kan være en scene for skrekkelige hendelser; den er badestrand og økologisk mareritt, et sted for promenade og kjærlighet, og et terreng for kamp, flukt og død. Disse estetiske rommene er til syvende og sist uttrykk for hvordan vi bebor verden. Stranden som et eget estetisk rom er et produkt av Ingolds taskscapes - den er en del av den til enhver tid produserte omverden og derfor også formet av dette. Det som historisk utmerker dens Umwelt, som ligger til grunn for det 21. århundres forskjellige strand-topos, er at strandens topografiske realitet, det den er i kraft av å være Umgebung, ikke lenger er gitt, men derimot fremstår som et kvasi-objekt, en natur-kultur hvis umiddelbare geologiske skjebne avhenger av menneskearten som $\mathrm{i} ø$ kende grad formgir den. Ikke desto mindre er det samlet i strandens topologiske historie ressurser som kan mobiliseres i arbeidet med å ivareta en strand med henblikk på dens eksistensmodus som natur, som en del av vårt eksistensgrunnlag og med henblikk på dens estetiske potensial både i sanselig og i kritisk forstand.

KNUT OVE ELIASSEN (f. 1959), dr. philos., professor i allmenn litteraturvitenskap, NTNU. Seneste bøker er Europeisk litteratur fra Columbus til Kant. Bind 3 "Samfunnet» (red. Knut Ove Eliassen og Anne Fastrup) 2019, Contested Qualities (red. Knut Ove Eliassen, Jan Fredrik Hovden \& Øyvind Prytz), 2018, Foucaults begreper, 2016. Han var medredaktør på K\&K nr 123 (2017) Topos som dette nummeret knytter an til. 
206 KULTUR \& KLASSE *130*2020 STRANDEN

\section{TOPOLOGIES OF THE BEACH}

Beaches are the order of the day, ecologically, politically, and economically. Globally, the world's population emigrates to the shorelines. The predicament referred to as the Anthropocene has made apparent the complexity of beaches as nature-culture-hybrids - ecotones - where biotopes and cultural practices meet, intersect and blend. Whether the issue at stake is production, pastime or pollution, the topicality of the beach remains unquestionable.

Drawing on E.R. Curtius' historical study of topology and anthropologist Tim Ingold's notion of taskscape the article identifies, analyses and discusses clusters of topoi lifted from the cultural history - literature, visual arts - of the beach. From the beaches of Troy by way of the Scheveningen beach of Dutch painters and the sun worshippers of mass tourism to the plastic beach of the 21st century, the ambition is to sketch out the many complexities that inform the Western conception of the beach, how they have had and still have an immediate bearing on the way we organize our life worlds and how the beach becomes a nexus for a permanently ongoing negotiation of the nature culture divide.

\section{KEYWORDS}

NO: strand; locus amoenus; taskscape; badestrand; Curtius; Ingold; antropocene; topologi

EN: beach; locus amoenus; taskscape; seaside resort; Curtius; Ingold; anthropocene; topology

\section{LITTERATUR}

Adorno, Theodor W. "Das Naturschöne", i Ästhetische Theorie. Frankfurt am/Main: Suhrkamp 1970.

Austen, Jane. Sanditon. London: Hesperus, 2009.

Baudelaire, Charles. "Invitation au voyage". Les Fleurs du mal, Paris: Ed. de la Pléiade, Gallimard, 1975.

Ballard, James. Cocaine Nights. London: Fourth Estate, 2009.

"A Boat full of migrants Boat lands at a popular Tourist Beach in southern Spain". BBC, 10. august 2017 https://www.youtube.com/watch?v=boon6MkE7UI 


\section{KNUT OVE ELIASSEN STRANDENS TOPOLOGIER}

Berman, Marshall. All That is Solid Melts into Air. New York/London: Penguin books, 1988. Calvino, Italo. Palomar. Oslo: Aschehoug, 1986.

Camus, Albert. L'Étranger. Paris: Nrf, Gallimard 2010 [1942].

Carson, Rachel. The Edge of the SeaAround Us. New York London: Oxford UP, 1998 [1955].

Carson, Rachel. The Sea Around Us. New York London: Oxford UP, 1961 [1950].

Christian Vs Lov (1688) https://www.hf.uio.no/iakh/tjenester/kunnskap/samlinger/tingbok/kilder/chr5web/chr5_04_04.html

Corbin, Alain. Le territoire du vide. L'occident et le désir du rivage. Paris: Flammarion, 1990.

Defoe, Daniel. Robinson Crusoe. W. W. Norton Critical Editions, 2, utg., New York, 1993 [1719].

Curtius, Ernst Robert. Europäische Literatur und lateinisches Mittelalter. Bern: Franke, 1948.

Curtius, Ernst Robert. "Historisk topik" K\&K - Kultur og klasse, "Topos" 123 (2017): 13-22.

Dahl, Christian, Eliassen, Knut Ove og Michael Høxbro Andersen, "Toposlærens aktualitet" K\&K - Kultur og klasse, "Topos" 123 (2017): 3-12.

Diderot, Denis. Salonerne 1759-1781. København: Edition Bløndal, 1997.

Diderot, Denis. Voyage de Hollande. Euvres complètes, bd. XXIV. Paris: Hermann, 2005.

Douglas, Mary. Purity and Danger. An Analysis of the Concepts of Pollution and Taboo. London: Ark, 1966.

Eliassen, Knut Ove. "Catastrophic Turns - from the Literary History of the Catastrophic", i The Cultural Life of Catastrophes and Crises. Red. Meiner, C \& K. Veel. Berlin: De Gruyter, 2012: 33-58.

Foucault, Michel. Surveiller et punir. Paris: Gallimard, 1975.

Foucault, Michel. Le Corps utopique, Les Hétérotopies, Paris: Nouvelle ligne 2009.

Fitzgerald, Scott. Tender is the Night. London: Penguin Classics, 1998.

Gillis, John R. The Human Shore, Chicago: Chicago University Press 2012.

Gilpin, William. Observations, on the Coasts of Hampshire, Sussex, and Kent, relative chiefly to Picturesque Beauty made in the summer of the year 1774. s.1., 1804.

Giltaij Jeroen og Jan Keltch. Herren der Meere - Meister der Kunst. Rotterdam - Berlin: Museum Boijmans \& Staatliche Museen zu Berlin, 1997.

Gorillaz, Plastic Beach https://genius.com/albums/Gorillaz/Plastic-beach

Hall, Stuart, Jessica Evans \& Sean Nixon. Representation. Second Edition. London: Sage, 2013.

Heller-Roazen, Daniel. The Enemy of All. Piracy and the Law of Nations. New York: MiT Press, 2009.

Herodot, Historie, bd 1. Oslo: Aschehoug, 1960.

Hohn, Donovan. Moby Duck. The True Story of 28,800 Bath Toys Lost at Sea. New York: Penguin Putnam, 2012.

Homer, The Odyssey, vol 1 og 2, Loeb Classical Library. Cambridge Mass. og London: Harvard University Press, 1995.

Ingold, Tim. "The Temporality of the Landscape", i The Perception of the Environment. London: Routledge, 2000.

Jowell, Claire. The Culture of Piracy. London: Ashgate, 2010. 
208 KULTUR \& KLASSE $* 130 * 2020$ STRANDEN

Lapelytė, Lina, Vaiva Grainytė og Rugilè Barzdžiukaitè. Sun and Sea (Marina). https://www. sunandsea.lt/Sun-and-Sea_libretto.pdf

https://www.youtube.com/watch?v=p_GoVtNag5k

Latour, Bruno. Vi har aldri vært moderne. Oversatt av Ragnar B. Myklebust. Oslo: Spartacus, 1996.

Lenček, Lena og Gideon Bosker. The Beach. The History of Paradise on Earth. London: Secker \& Warburg, 1998.

Mann, Thomas. Der Tod in Venedig, i Die Erzählungen. Frankfurt/am Main: S. Fischer Verlag, 2005 [1913].

L'ordonnance de la marine (1681) http://www.fortunes-de-mer.com/mer/images/documents\%20pdf/legislation/Francaise/Ordonnance\%20Colbert\%201681.pdf

Poix, Guillaume. Les fils conducteurs. Paris: Gallimard, 2017.

Riding Christin \& Richard Jones. Turner and the Sea. London: Thames \& Hudson, 2013.

Roberts, Callum M. An Unnatural History of the Sea. Washington DC: Island Press, 2010.

Schmitt, Carl. Nomos der Erde im Völkerrecht des Jus Publicum europaeum. Berlin: Dunker \& Humblot, 1950.

Taussig, Michael. "The Beach (A Fantasy)", Critical Inquiry 262 (2000): 248-278.

Thoreau, Henry David. Cape Cod i A Week on the Concord and the Merrimack Rivers \&c. New York: The Library of America, 1985.

Thukydid, Peloponeserkrigen, bd. 1. Oslo: Aschehoug, 1962.

Veblen, Thorstein. The Theory of the Leisure Class. Oxford: Oxford University Press, 2009. Vergil, Aeneiden, bok 5. Tangen: Suttung forlag, 1985. 